\title{
PARSEC 翼型表現法の修正手法と表現性能検証*1 Modification of PARSEC Airfoil Representation and Investigation of Design Performance
}

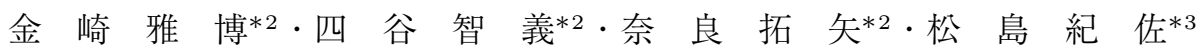 \\ Masahiro Kanazaki, Tomonori Yotsuya, Takuya NARA and Kisa Matsushima
}

Key Words : Airfoil Representation, Genetic Algorithms, CFD

\begin{abstract}
The original PARSEC (PARametric SECtion) method can satisfactorily solve the optimization problems involving transonic airfoils by using a few design variables. However, it is difficult to apply this method to the design of airfoils under other conditions such as supersonic flow and low Reynolds number flow. To solve various airfoil design problems by using a few design variables and the PARSEC representation, a modified PARSEC representation is proposed. The capability of the proposed modified representation to solve unknown real-world design problems is investigated; the proposed representation is used along with multi-objective genetic algorithms to solve two types of problems. One is the design of a conventional transonic airfoil that is to be used in the Earth's atmosphere; the other is the design of an airfoil that is to be used in the Martian atmosphere. To evaluate the aerodynamic performance of the airfoils, the structured Navier-Stokes solver is used. The results indicate that better solutions can be obtained by using the proposed PARSEC modification than by using the original PARSEC representation, especially in the Martian atmosphere.
\end{abstract}

\section{1.は じめに}

数值流体力学 (CFD) の発達とともに, 最適化アルゴリ ズムなどを組み合わせて要求性能を満たす翼型をミッショ ンごとに設計することが一般的になってきており，設計コ ストを抑えるためにも効率的に翼型などを表現する必要が ある. CAD を用いるときには自由度の高い曲線を描くこと ができる Non-Uniform Rational B-Spline（NURBS）等 によることが多い. NURBS は高い自由度で滑らかな曲線 を描くが, 各制御点のパラメータと空力関係の対応関係が 取りにくく設計知識の構築には不向きと思われる. 一方, 翼 型の幾何学的特徵を高亜音速流れと対応させて関数化した PARSEC 法1)では, 比較的少ない設計変数により翼型を表 現し, 各変数の空力的特性への寄与度も解析しやすいこと も特徵と言える。しかし, 翼型学では本来キャンバ上にある べき前縁半径の中心 $r_{\mathrm{le}}$ を, 文献 1) 等による PARSEC 法 では第 1 図に示すようにコード軸上で明示的に定義してい るため, 前縁付近でキャンバが大きい翼型をうまく表現で きない等, 表現性に限界がある。この問題を解決するため, 翼型をキャンバと厚み分布に分けて定義した修正 PARSEC 法 $^{2)}$ が提案され, JAXA 超音速実験機 NEXST1に適用さ れた超音速翼型も表現できることを示した，その一方で，多 様な問題に適用が期待されるこの表現手法が未知の翼型設 計問題に対しどの程度の解決能力を有するかの検討は依然

\footnotetext{
*1 (C) 2011 日本航空宇宙学会

平成 22 年 6 月 3 日原稿受付

*2 首都大学東京大学院システムデザイン研究科

*3 富山大学大学院理工学研究部
}

必要と考えられる。そこで，本報告では PARSEC 法と修 正 PARSEC 法を実際の翼型設計問題に適用し，比較する. 一般的な遷音速翼型設計の他に, 我が国でも研究が進めら れている火星探査航空機に対応した翼型設計問題3)により, 未知の問題への解決能力を検証する.

\section{2. 比較する翼型表現手法}

2.1 PARSEC 法 本研究では 11 の変数で表現する PARSEC11 法を比較対象とする. 文献 1)によるこの手法 は第 1 図に示すように上下面を分離して定義し, 前縁半径 も変数として直接操作したうえで上下面を連続的につなぐ. $x-z$ 平面において翼断面の上下面を表す曲線は $x$ の多項式 (1) で与えられる.

$$
z=\sum_{n=1}^{6} a_{n} \times x^{\frac{2 n-1}{2}}
$$

$a_{n}$ は実数係数であり, 第 1 図中の 11 の設計パラメータ（上 下面の最大翼厚の座標 $\left(x_{\mathrm{up}}, z_{\mathrm{up}}\right),\left(x_{\mathrm{lo}}, z_{\mathrm{lo}}\right)$, 及びそこで の曲率 $z_{\mathrm{xxup}}, z_{\mathrm{xxlo}}$, 前縁半径 $r_{\mathrm{le}}$, 後縁高さ $z_{\mathrm{te}}$, 後縁角 $\alpha_{\mathrm{te}}$, 後縁開き角 $\beta_{\mathrm{te}}$, 後縁厚み $\Delta z_{\mathrm{te}}$ ) を用いて表される 連立方程式を解くことで求められる。本研究では $\Delta z_{\mathrm{te}}$ を 0 としたので残りの 10 のパラメータを用いて翼型を表現 する。

2.2 修正 PARSEC 法 PARSEC 法では前縁半径の 中心がコード軸上にあり, 表現性能を下げることがある。こ うした問題を解決するために修正手法 ${ }^{2)}$ では第 2 図 (a) の ように翼型をキャンバと厚みに分けて定義する。キャンバ 
は式 (2) で与え, 第 2 図 (b) に示す設計変数（最大キャン バでの座標 $\left(x_{\mathrm{c}}, z_{\mathrm{c}}\right)$ と曲率 $z_{\mathrm{xxc}}$, 後縁の $z$ 座標 $z_{\mathrm{te}}$, 後縁 角 $\left.\alpha_{\mathrm{te}}\right)$ で係数を決定する.

$$
z=\sum_{n=1}^{5} b_{n} \times x^{n}
$$

厚み分布については，PARSEC 法を対称翼と考えた時と 同様に定義し，5つの設計変数（最大翼厚の座標 $\left(x_{\mathrm{t}}, z_{\mathrm{t}}\right)$ $\left(=\left(x_{\mathrm{up}}, z_{\mathrm{up}}\right)\right)$, そこでの曲率 $z_{\mathrm{xxt}}\left(=z_{\mathrm{xxup}}\right)$, 前縁半径 $r_{\mathrm{le}}$, 後縁開き角 $\left.\beta_{\mathrm{te}}\right)$ で上面のみを定義する。結果, この 手法でも 10 個の変数によって翼型を表現できる.

\section{3. 翼型形状表現性能}

3.1 検証手法 本研究では多目的遺伝的アルゴリズム $(\mathrm{MOGA})^{4)}$ を用いて, 迎角 2 度における抵抗係数 $C_{d}$ 最 小化と揚力係数 $C_{l}$ 最大化の二目的問題に関して大域解を 得る. 空力性能は $\mathrm{C}$ 型構造格子に基ついて Navier-Stokes 方程式を解いた。本検証では 2 通りの飛行環境を考える。 一つは PARSEC 法でも念頭に置かれているマッハ数 0.8 レイノルズ数 $10^{7}$ の一般的な遷音速条件 (Case 1), もう 一つはマッハ数 0.48 , レイノルズ数 25977 の Case 2 とす る. Case 2 は火星探査航空機の翼型設計に対応しており, PARSEC 法では想定されていない環境である.

3.2 MOGA による結果 第 3 図にMOGAにより概 ね収束したと見られる探索結果の比較を示す. PARSEC 法 と修正手法を比較すると, Case 1 (第 3 図) ではPARSEC 法と修正手法共に，同程度の非劣解集合を得ることができ ており, 遷音速環境では修正法も妥当な表現性能を有して

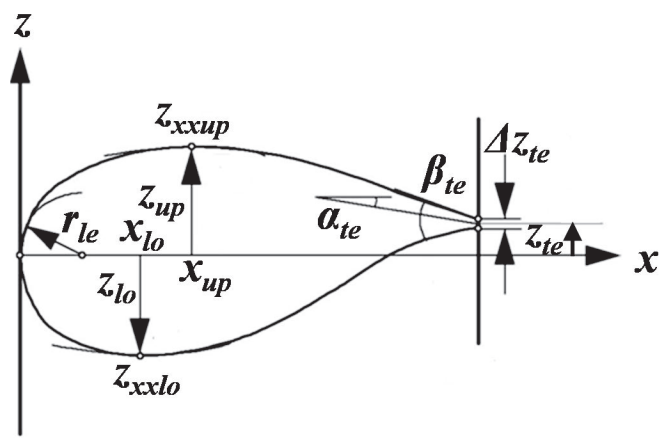

第1図 PARSEC 法 ${ }^{1)}$
いると言える。 また, Case 2 (第 4 図) において PARSEC 法と修正手法とを比較すると, 修正手法ではどの $C_{l}$ でも $C_{d}$ が 150 counts 程改善されている。これは元の PARSEC 法は地球での遷音速飛行に特化した方法であるのに対し, 修正手法は未知の環境における翼型も最適に表現できるこ とを示している。第 5 図には Case 2 で得られた非劣解の うち揚抗比 $(l / d)$ が最も高いものを選択し, 形状と流れ場 (マッハ数) を比較したものである. 得られた最大 $l / d$ は PARSEC 法では $31.0\left(C_{l}=0.65, C_{d}=0.0211\right)$ であっ た一方で, 修正 PARSEC 法では $58.0\left(C_{l}=0.44, C_{d}=\right.$ $0.0076)$ となり, 形状も修正 PARSEC 法によるもののほう が滑らかである。結果として，修正法では後縁からの剝離 を弱めることができており，より小さな $C_{d}$ を示す翼型を 得ることができたと考えられる。

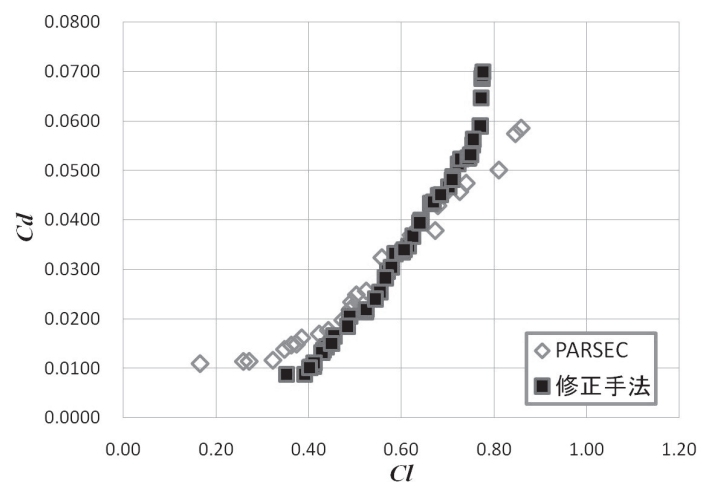

第 3 図 MOGA により得た非劣解（Case 1）

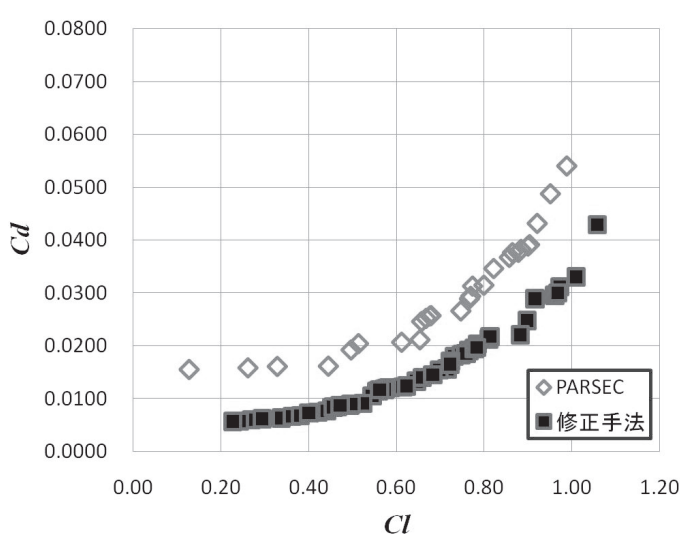

第 4 図 MOGA により得た非劣解（Case 2)

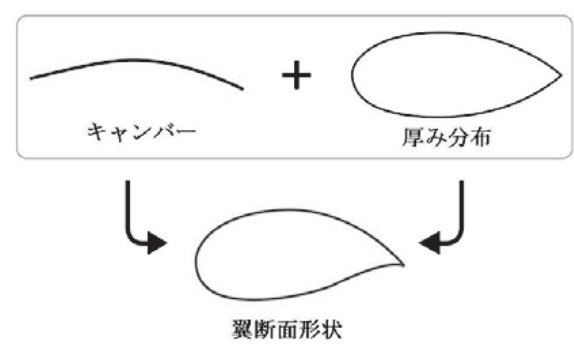

(a) キャンバの分離

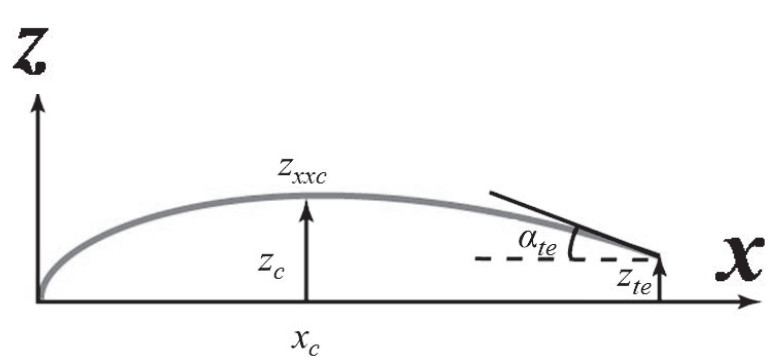

(b) キャンバの定義

第 2 図 修正手法 


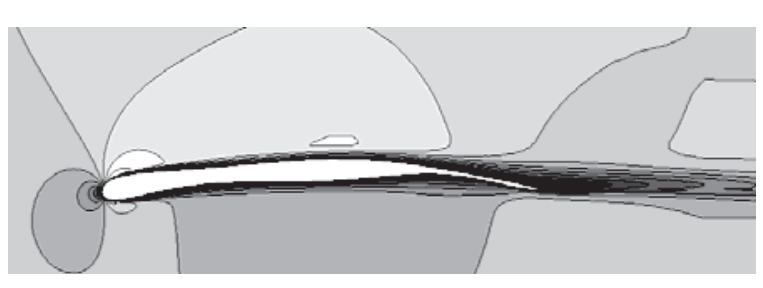

(a) PARSEC 法

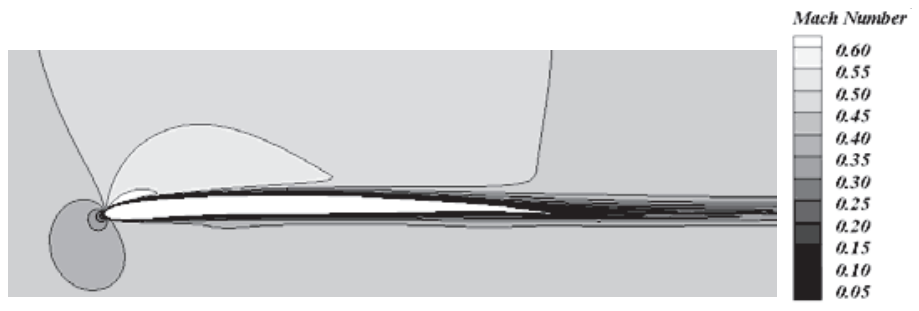

(b) 修正 PARSEC 法

第 5 図 Case 2 で得た揚抗比最大の形状

\section{4. ま と め}

本研究ではMOGA を用いて, 翼厚とキャンバに設計変 数を与える修正 PARSEC 法による翼型表現性能の検証を 行った。 その結果, 修正法は地球環境での高亜音速域で従 来の PARSEC 法と同程度の性能を示した。 また，火星探 査航空機を仮定した環境では従来の手法よりもより良い結 果を示した。これらのことから修正法は従来の PARSEC 法よりも形状表現の自由度が高められていると言える.

これらのことは修正法が翼の空力設計に有望であること を示しており, 今後, 揚力制約つき問題や超音速翼設計問題
など，様々な実用問題を良好に解決することが期待できる.

\section{参 考 文 献}

1) Sobieczky, H.: Parametric Airfoils and Wings, Notes on Numerical Fluid Mechanics, Vol.68, 1998, Vieweg Verlag, pp. 71-88.

2）松澤拓未，松島紀佐，中橋和博：効率的精密設計を可能にする超 音速翼 CFD 設計手法, 第 40 回流体力学講演会/航空宇宙数值シ ミュレーション技術シンポジウム 2008 講演集, 2008, pp. 3-6.

3) 大山 聖, 藤井孝蔵: 火星探査飛行機翼型の空力設計最適化, 日 本機械学会流体工学部門講演会講演論文集, 2005 [CDROM].

4) Kanazaki, M.: Multi-Objective Design Optimization System for a Subsonic Diffuser, AIAA Paper 2004-6513, 2004. 